\title{
The need to provide students and educators with the tools to cross the digital divide
}

\author{
Elba Ramirez \\ Auckland University of Technology \\ elba.ramirez@aut.ac.nz
}

Keywords: digital poverty \& illiteracy; digital divide; technology-enhanced learning \& teaching.

\section{Abstract:}

2020 will be remembered as an unprecedented 'global' socio-economic and educational crisis. As a lecturer in a tertiary institution in Aotearoa New Zealand, this pandemic has heightened my awareness of inequalities in education and the impacts these have had on students and educators. Educational institutions around the world decided to continue teaching and learning online to ensure physical distancing among students, as if institutions, lecturers/teachers, and students, among others, were prepared for this shift. As a result of this shift, digital poverty and illiteracy are considered for some to have 'emerged' from the pandemic (Baker, 2020) failing to recognise the pre-existing digital divide (Ayre, 2020; Holmes \& Burgess, 2020; Ouahidi, 2019; Wolstencroft \& Zhou, 2020). However, these are problems that governmental and educational institutions have neglected to address until the pandemic rendered these issues unavoidable. Both students and lecturers were affected. For example, many lecturers were unfamiliar with online learning tools and/or strategies for online teaching and/or lacked appropriate devices and/or access to stable internet connections. Similarly, many students struggled with online platforms, such as Blackboard, or did not have access to devices or internet connections. The high demand from both students and lecturers for support from their educational institutions overwhelmed tech support infrastructures, revealing the neglectful assumption that these issues did not already exist (Ayre, 2020; Madianou, 2020; Montacute, 2020; Norris, 2001). As an educator, this year was particularly challenging because it made me reflect on how accessible my teaching practice was, how I could respond to digital poverty and illiteracy, and what gaps remained. Nonetheless, I also learnt many lessons about the amazing possibilities that technology-enhanced education can offer. This conference addresses many of these innovations, which will inspire educators. Learning can undoubtedly be enhanced by technology but this presentation endeavours to start a conversation about what changes are necessary to ensure that all students have access to what they need for their learning to be technologically supported and for lecturers to be able to utilise technological enhancements in their practices. I provide a range of instances from my practice where I tried to address the aforementioned issues and some examples of the limitations I encountered.

\section{References}

Ayre, L. B. (2020). What More Can We Do to Address Broadband Inequity and Digital Poverty?. Information Technology and Libraries, 39(3). https://doi.org/10.6017/ital.v39i3.12619

Baker, J. (2020). 'Digital poverty': emergence of a new kind of poor. The Sydney Morning Herald. https://www.smh.com.au/education/digital-poverty-emergence-of-a-new-kind-of-poor-20201117-p56fek.html

Holmes, H. \& Burgess, G. (2020). "Pay the wi-fi or feed the children": Coronavirus has intensified the UK's digital divide. https://www.cam.ac.uk/stories/digitaldivide

Madianou, M. (2020). A Second-Order Disaster? Digital Technologies During the COVID-19 Pandemic. Social Media + Society, 6(3). https://doi.org/10.1177/2056305120948168

Montacute, R. (2020). Social mobility and Covid-19. Implications of the covid-19 crisis for educational inequality. The Sutton Trust. https://www.suttontrust.com/wp-content/uploads/2020/04/COVID-19-and-SocialMobility-1.pdf

Norris, P. (2001). Digital divide? Civic engagement, information poverty and the internet in democratic societies. Cambridge, UK: Cambridge University Press. 
Ouahidi, L. M. (2019). Constraints on Developing Digital Literacy Skills in Higher Education. International Journal of Linguistics, Literature and Translation (IJLLT). https://ssrn.com/abstract=3546856

Wolstencroft, P., \& Zhou, X. (2020). The Digital Literacy Myth: not all are natives. Web publication/site, Advance HE. https://www.advance-he.ac.uk/news-and-views/The-Digital-Literacy-Myth 